\title{
Anti-IgE for the Treatment of Allergic Rhinitis - and Eventually Nasal Polyps?
}

\author{
Katia Verbruggen Paul Van Cauwenberge Claus Bachert \\ Upper Airway Research Laboratory, Department of Otorhinolaryngology, Ghent University Hospital, \\ Ghent, Belgium
}

\section{Key Words}

Allergic rhinitis • lgE • Nasal polyps · Omalizumab •

Staphylococcus aureus enterotoxins $\cdot$ Superantigens

\begin{abstract}
In allergic rhinitis, cross-linking of IgE molecules upon allergen contact induces degranulation of mast cells and basophils within the mucosal tissue and results in the release of typical mediators, which consecutively induce the wellknown symptoms. Omalizumab counteracts these interactions by reducing serum levels of free lgE. Therapy targeted at $\lg E$ also interferes with its binding to the low-affinity receptors inhibiting the amplification of the $\mathrm{Th}_{2}$-type response. Treatment of allergic rhinitis with anti-lgE has been shown to be safe and to reduce specific symptoms. Furthermore, the combination of omalizumab with specific immunotherapy may not only increase efficacy but also safety in selected patients. Therefore, we reviewed previously published studies on omalizumab therapy in allergic rhinitis, either as monotherapy or in combination with immunotherapy. In patients with nasal polyps, a local multiclonal IgE response has recently been described, initiated by Staphylococcus aureus-derived enterotoxins, which at least modifies the inflammatory reaction within the tissue. Evidence accumulates that these enterotoxins act as superantigens resulting in a multiclonal $\mathrm{T}$ - and $\mathrm{B}$-cell activation with massive $\lg \mathrm{E}$ formation within the airways. Because of the multiclonality,
\end{abstract}

a range of allergens could possibly maintain a constant degranulation of mast cells present in the polyp tissue, which may contribute to disease severity. We here discuss a proofof-concept treatment trial with omalizumab in nasal polyposis, which - in case of a positive therapeutic response - would also pave the way for anti-lgE treatment approaches for severe non-atopic lower airway disease.

Copyright $\odot 2008$ S. Karger AG, Basel

\section{Introduction}

In both allergic rhinitis and nasal polyposis, IgE is increased in diseased mucosal tissue and (frequently) also in the serum of patients. Whereas the role of IgE in type1 allergic diseases has been clarified, with IgE cross-linking inducing the degranulation of basophils and mast cells upon contact with an allergen, in nasal polyps the role of IgE remains to be elucidated. We recently described a multiclonal IgE response to superantigens in nasal polyp tissue, which is partially reflected in the periphery [1-3]; how far IgE and mast cell degranulation contribute to this disease still needs to be clarified.

Clinically, natural allergen exposure - either perennially or seasonally - or artificial allergen exposure in nasal provocation studies evokes the typical symptoms in allergic rhinitis patients, consisting of sneezing, itching, secretion and obstruction. Also, typical mediators such as

\section{KARGER}

Fax +4161306 1234 E-Mail karger@karger.ch www.karger.com
Correspondence to: Prof. Claus Bachert

Upper Airway Research Laboratory

Department of Otorhinolaryngology, Ghent University Hospital

De Pintelaan 185, BE-9000 Ghent (Belgium)

Tel. +32 9240 2332, Fax +329240 4993, E-Mail Claus.Bachert@ugent.be 
histamine, leukotrienes and prostaglandins have been found to be increased in nasal secretions of sensitized patients due to both natural and artificial exposure [4-6], whereas IgE-negative subjects normally do not respond to the allergen. However, patients with nasal polyps even those with a positive skin test - do obviously not respond to allergen exposure during the season, neither with symptoms nor with mediator release [7].

Levels of circulating allergen-specific IgE have been shown to be correlated with symptom scores in highly sensitive allergic rhinitis patients [8], and IgE itself regulates the expression of FceR1 receptors on mast cells and basophils. High IgE levels will result in a greatly enhanced surface expression of FceR1 receptors on mast cells and basophils [8-11]. Long-term treatment with omalizumab reduces the density of high-affinity FceR1 receptors, and, consecutively, less IgE is bound. Furthermore, low-affinity receptors (FceR2 or CD23) are expressed on monocytes, macrophages, lymphocytes, and epithelial and dendritic cells, and recognize and bind IgE. Cross-linking of mast cell-bound IgE by an allergen results in activation of these cells leading to immediate hypersensitivity responses. IgE has been ascribed an important role in $\mathrm{T}$-cell responsiveness since antigen-IgE complexes have been shown to increase the antigen-presenting capacity of B cells [12] and to amplify the T-cell response to allergen, mostly mediated through the lowaffinity $\operatorname{IgE}$ receptor $[12,13]$. Therapy targeted at IgE interferes with its binding to the low-affinity receptors and, in the long-term, indirectly to the high-affinity receptors, inhibiting the amplification of a $\mathrm{Th}_{2}$-type response. Through inhibition of mast cell degranulation it also reduces airway responses at several stages of the allergic reaction (in acute allergic reactions, which develop within seconds or minutes of allergen exposure, and in latephase reactions, which develop within hours after allergen exposure) [13], and has been shown to reduce allergic rhinitis symptoms successfully $[14,15]$.

In contrast, the use of anti-IgE in nasal polyposis is a new approach, unrelated to atopy and, if proven effective, would clearly add a new perspective to the anti-IgE treatment approach not only for nasal polyps; this approach could be also of relevance for severe asthma, which shares multiclonal IgE formation and an immune response to staphylococcal enterotoxins [2]. We here review the current studies on omalizumab in allergic rhinitis, both as monotherapy and in combination with specific immunotherapy (SIT), and provide a rationale for the treatment of multiclonal IgE in nasal polyp disease.

\section{Allergic Rhinitis and Omalizumab: Rationale and Mode of Action}

Allergic rhinitis is the most common clinical presentation of atopic disease [16]; estimates of the prevalence of allergic rhinitis in Europe range from 9 to $42 \%$ [17]. Currently, its treatment consists of allergen avoidance measurements, pharmacologic interventions like antihistamines and corticosteroids, and immunotherapy (IT), which provide relief of symptoms but are often insufficient to totally control the disease or may be associated with significant side effects. Therefore, the search for an effective and safe treatment of allergic rhinitis is thus not completed.

In an IgE-mediated type I hypersensitivity reaction such as allergic rhinitis, IgE attaches to inflammatory cells like mast cells, basophils and dendritic cells, with the Fc portion of the IgE binding to the Fce receptors. Two types of receptors mediate the biological activities of IgE: a high- (FceR1) and a low-affinity receptor (FceR2 or CD23). In allergic patients, mast cells express an increased number of FceR1 receptors. Inhaled allergens bind to IgE on the surface of mast cells and basophils, inducing cross-linkage of IgE and aggregation of FceR1, and triggering the release of histamines, leukotrienes and other inflammatory mediators, leading to the onset of allergic symptoms $[4,18]$. Following antigen presentation by the antigen-presenting cells to $\mathrm{Th}_{2}$ cells, $\mathrm{Th}_{2}$ cells will release mediators like IL-4 that will stimulate allergenspecific B cells (which are also stimulated through the $\mathrm{B}$-cell antigen receptor) leading to differentiation of $\mathrm{B}$ cells into IgE-secreting plasma cells [18]. Further contact will result in the production of IgE that will bind to the high-affinity IgE receptors of the mast cells and basophils and the low-affinity IgE receptors on several cells (B, T, Langerhans and dendritic cells, macrophages, monocytes, platelets, neutrophils and eosinophils) $[18,19]$. Acting mostly through $\mathrm{Fc} \varepsilon \mathrm{R} 2$, IgE appears to play a role in the induction of a $\mathrm{Th}_{2}$-type response [19] and forms part of a positive feedback loop leading to further increases in $\operatorname{IgE}$ and airway eosinophilia [13].

Omalizumab (rhuMAb-E25) is a recombinant humanized IgG1 monoclonal antibody derived from the murine antibody MAE11. It specifically binds to the highaffinity FceR1 domain of free circulating IgE, but not to IgG or IgA [16], and thus prevents binding of free serum IgE to mast cells and other effector cells. Omalizumab causes a rapid decrease in serum IgE levels, reduces free IgE levels and downregulates the expression of IgE receptors (FceR1) on mast cells and basophils [9, 16, 20-25]. 
Furthermore, a significant decrease in surface FceR1 expression caused by omalizumab is also seen on dendritic cells, which are potent antigen-presenting cells. In both basophils and dendritic cells, the decrease in FceR1 expression is proportional to the reduction in serum free IgE [26]. The downregulation of Fc $\varepsilon$ R 1 on basophils can be explained by two mechanisms: (1) anti-IgE captures IgE molecules, after which free IgE molecules become too sparse to bind the receptors, or (2) unoccupied receptors on basophils are endocytosed and not replenished. Basophils have a life span of about 2 weeks; thus, in longer terms, the old pool of basophils in the blood is replaced by a new basophil pool that, because of the low free IgE levels, has not gone through upregulation of FceR1 [27]. In skin mast cells, omalizumab also induces a downregulation of FceR1 receptors, but in contrast to basophils the time course for the decrease in FceR1 expression in mast cells is slower [28]. The decrease in FceR1 expression in skin mast cells is associated with a decrease in the acute wheal size after the allergen skin test [28]. Results of a study by Ong et al. [29] showed a more marked effect of anti-IgE treatment on late-phase reactions and prevention of the repeat-dose priming effect on inflammatory cells compared with early-phase skin reactions. This supports a role for omalizumab in chronic allergic conditions. By downregulating FceR1 expression, anti-IgE might inhibit allergen presentation to T cells, possibly resulting in decreased allergen-specific T-cell activation, thus being able to block both the sensitization and effector phases of allergen-specific immune responses $[10,26]$. Omalizumab also inhibits in vitro allergen-induced IgE synthesis by peripheral blood mononuclear leukocytes from atopic volunteers $[4,16]$. Figure 1 summarizes the effect of omalizumab on the allergic cascade.

Total serum IgE and allergen-specific total serum IgE increase during treatment with omalizumab because of the formation of omalizumab-IgE complexes with a longer serum half-life than free IgE [16]. Immune complexes are generally considered harmful; however, these immune complexes did not cause serum sickness, inflammation or other adverse events [27]. In fact, Chang [27] suggested that these IgE-anti-IgE complexes are in fact beneficial, because, although they can no longer bind to FceR1, they can still bind to allergens and serve as competitive inhibitors reducing the contact of the allergens with FceR1-bound IgE. Omalizumab does not provoke histamine release from IgE-sensitized mast cells because it does not interact with cell-bound IgE. Finally, omalizumab will inhibit allergen-induced responses regardless of allergen specificity because omalizumab does not bind to the variable allergen-specific region of the IgE molecule [10].

In patients with allergic rhinitis, anti-IgE reduces in vitro leukotriene release by peripheral leukocytes stimulated with allergen, showing a decrease in mediator release by effector cells [30]. The concentration of tryptase (a mast cell mediator) in nasal secretions was significantly lower in anti-IgE-treated patients compared to placebotreated patients [5]. Blood eosinophils and eosinophils in nasal tissue were present in significantly lower numbers in omalizumab-treated allergic rhinitis patients than in placebo-treated patients during pollen exposure. A significant correlation between blood and tissue eosinophil levels and serum free IgE levels was found [25]. This could partly be explained by the fact that omalizumab prevents mast cell activation and the release of cytokines (e.g. IL-5) and inhibits subsequent eosinophil chemotaxis [10].

Suppression of serum free IgE to the lowest levels of detection requires a ratio of approximately 10-15:1 omalizumab/total IgE (free IgE and complexed IgE). Thus, doses and dosing frequency should be based on the total serum IgE level measured at the start of treatment and body weight. Steady-state concentrations of total omalizumab are generally achieved by days $14-28$ after subcutaneous and intravenous administration, respectively. After multiple-dose subcutaneous or intravenous administration of omalizumab, total omalizumab clearance is slow, with a mean half-life of 2.9 weeks. Omalizumab was found to be most concentrated in serum; no specific organ deposition was observed, and no antibodies against omalizumab were detected [16]. Immune complexes are eliminated by urinary excretion [31]. Although both the subcutaneous and the intravenous routes were effective, aerosolized anti-IgE did not suppress serum IgE levels and did not alter asthmatic response to allergen [22, $32,33]$. Thus, the administration of aerosolized omalizumab is not considered to be useful. Furthermore, one individual treated with aerosolized omalizumab developed antibodies against omalizumab [33]. The effect of omalizumab on allergen-induced nasal response was measurable within 2 weeks [24]. To protect patients from allergic symptoms during the pollen season, administration of omalizumab should start at least 1 week before and continue throughout the pollen season [34].

Two studies were conducted to assess the efficacy of omalizumab after nasal allergen challenge in allergic rhinitis patients $[4,24]$. In both studies, nasal response to allergen challenge was inhibited compared to the placebo group. Omalizumab induced a significant decrease in TNF- $\alpha$ levels in the pre-challenge nasal lavage fluid, sug- 
gesting an anti-inflammatory effect [4]. Additionally, the increase in human serum albumin in the nasal lavage fluid after allergen challenge was also inhibited after omalizumab treatment. This indicated that the effect of omalizumab could partly be caused by preventing the increase in vascular permeability, which is commonly seen after allergen challenge due to the inflammation [4].

\section{Results from Clinical Studies in Allergic Rhinitis}

In 1997, Casale et al. [16] included 240 subjects with ragweed-induced allergic rhinitis, who were divided into five treatment groups. One hundred eighty-one subjects received first an intravenous loading dose of omalizumab and then $0.15 \mathrm{mg} / \mathrm{kg}$ s.c. or 0.15 or $0.5 \mathrm{mg} / \mathrm{kg}$ i.v. for a 84 day treatment period followed by a 42 -day observation period. A subcutaneous and an intravenous placebo group were included. Omalizumab decreased serum free IgE in a dose-dependent manner, and symptom scores correlated with ragweed-specific IgE levels. Only 11 subjects had suppression of IgE levels to undetectable levels; however, this sample was too small to demonstrate significant differences and clinical efficacy. Although no significant effect of anti-IgE was measured on symptom scores, the results suggested that omalizumab, given at an adequate dose, should be an effective treatment for allergic rhinitis.

Based on the results of this study, a second large multicenter study [14] including 536 patients with moderatesevere ragweed-induced allergic rhinitis was conducted to compare three subcutaneous doses of omalizumab (50, 150 and $300 \mathrm{mg}$ s.c.) with placebo. The administration schedule was based on baseline IgE levels. Patients with serum IgE levels of 30-150 IU/ml received omalizumab treatment in weeks 0,4 and 8 , and those with IgE levels of $151-700 \mathrm{IU} / \mathrm{ml}$ received treatment in weeks $0,3,6$ and 9. Treatment was started approximately 2 weeks before the onset of the ragweed pollen season. The mean daily nasal symptom severity scores rose with pollen counts in patients receiving placebo, but did not increase during the ragweed season in patients receiving $300 \mathrm{mg}$ of omalizumab. The difference between these two groups was statistically significant. Furthermore, the need for rescue medication was lower in the patients treated with $300 \mathrm{mg}$ omalizumab compared with the placebo group, and the rhinitis-related quality of life scores were better in patients who received $300 \mathrm{mg}$ of omalizumab than in the other groups. No difference between treatment groups was seen in the overall incidence of adverse events. This study provided clinical evidence that lowering systemic free IgE levels is effective in the treatment of seasonal allergic rhinitis. Additionally, in patients who were treated with omalizumab, the number of days the patients missed work, school or both decreased $75 \%$ compared with the placebo group, adding an important pharmacoeconomic aspect to the benefit of omalizumab treatment.

An extension of this study in patients treated with 300 $\mathrm{mg}$ s.c. omalizumab injections was done to assess whether omalizumab could be safely re-administered after treatment had been discontinued for a prolonged period $[35,36]$. The incidence of adverse events was similar to that reported in the previous study: no serious adverse events related to omalizumab occurred, and injection site reactions were few and mild. No anti-omalizumab antibodies were detected. Thus, retreatment with omalizumab during a second pollen season was well tolerated, and no significant immunologic reactions occurred.

Ädelroth et al. [15] conducted a study in 251 patients with birch pollen-allergic rhinitis who received omalizumab or placebo treatment during the birch pollen season. A dose of $300 \mathrm{mg}$ of omalizumab was given subcutaneously twice monthly (baseline serum IgE level $\leq 150 \mathrm{IU} / \mathrm{ml}$ ) or 3 times at 3 -week intervals (baseline serum IgE level $>150 \mathrm{IU} / \mathrm{ml}$ ) in order to achieve a reduction in free IgE levels below $25 \mathrm{ng} / \mathrm{ml}$, as suggested by Casale et al. [14]. Average daily nasal symptom severity scores, concomitant medication use and rhinitis-related quality of life was significantly better in the omalizumab group compared to the placebo group. Serum-free IgE levels were markedly lower in omalizumab-treated subjects, and this study also found an association between free IgE levels and data on clinical effectiveness. Omalizumab was well tolerated and no anti-omalizumab antibodies were detected. Unfortunately, the birch pollen season started early, causing pollen exposure to coincide with or precede the first dose of trial medication, which may have masked some of the beneficial effects of omalizumab.

Finally, 289 patients with moderate-severe perennial allergic rhinitis were treated with subcutaneous omalizumab [at least $0.016 \mathrm{mg} / \mathrm{kg} / \mathrm{IgE}$ (IU/ml) per 4 weeks] or placebo over 16 weeks. The mean daily nasal severity score was significantly lower in omalizumab-treated patients throughout the 16 weeks of treatment. Compared to placebo, omalizumab significantly reduced rescue antihistamines and improved rhinitis-related quality of life. Omalizumab was again safe and well tolerated [37]. For an overview on studies performed with omalizumab monotherapy in allergic rhinitis, please refer to table 1.

Omalizumab is a treatment that targets a common factor (IgE) in allergic rhinitis and asthma, serving as a sys- 
Table 1. Clinical studies with omalizumab in AR

\begin{tabular}{|c|c|c|c|}
\hline Study & Patients & Outcome: efficacy & Outcome: AE \\
\hline $\begin{array}{l}\text { Casale } \\
\text { et al. [16] } \\
(1997)\end{array}$ & $\begin{array}{l}240 \text { subjects with ragweed } \mathrm{AR} \\
\text { comparison omalizumab-placebo }\end{array}$ & $\begin{array}{l}\text { dose-dependent } \downarrow \text { in serum free IgE } \\
\text { correlation between symptoms and IgE levels }\end{array}$ & $\begin{array}{l}\text { no severe or serious AE related to } \\
\text { omalizumab } \\
\text { no difference in AE between study groups }\end{array}$ \\
\hline $\begin{array}{l}\text { Casale } \\
\text { et al. [14] } \\
(2001)\end{array}$ & $\begin{array}{l}536 \text { subjects with ragweed } \mathrm{AR} \\
\text { comparison omalizumab-placebo }\end{array}$ & $\begin{array}{l}\text { significant association between IgE reduction, } \\
\text { nasal symptoms and rescue medication use; } \\
\text { significantly lower NSSS, lower need for } \\
\text { rescue medication, better RRQoL scores, } \\
75 \% \text { reduction in days missed from work in } \\
\text { patients receiving } 300 \mathrm{mg} \text { omalizumab }\end{array}$ & $\begin{array}{l}\text { no difference in AE between study groups } \\
\text { no anti-omalizumab antibodies were } \\
\text { detected }\end{array}$ \\
\hline $\begin{array}{l}\text { Nayak } \\
\text { et al. [36] } \\
(2003)\end{array}$ & $\begin{array}{l}\text { retreatment of } 287 \text { subjects with } \\
\text { ragweed AR }\end{array}$ & $\downarrow$ in serum free IgE levels & $\begin{array}{l}\text { no severe or serious AE related to } \\
\text { omalizumab } \\
\text { no anti-omalizumab antibodies were } \\
\text { detected }\end{array}$ \\
\hline $\begin{array}{l}\text { Ädelroth } \\
\text { et al. [15] } \\
(2000)\end{array}$ & $\begin{array}{l}251 \text { patients with birch pollen AR } \\
\text { comparison omalizumab-placebo }\end{array}$ & $\begin{array}{l}\downarrow \text { serum free IgE levels with omalizumab } \\
\text { association between free IgE levels and clinical } \\
\text { outcome } \\
\text { mean daily NSSS, concomitant medication use, } \\
\text { RRQoL was significantly better with } \\
\text { omalizumab }\end{array}$ & $\begin{array}{l}\text { no difference in AE between study groups } \\
\text { no anti-omalizumab antibodies were } \\
\text { detected }\end{array}$ \\
\hline $\begin{array}{l}\text { Chervinsky } \\
\text { et al. [37] } \\
(2003)\end{array}$ & $\begin{array}{l}289 \text { subjects with perennial } \mathrm{AR} \\
\text { comparison omalizumab-placebo }\end{array}$ & $\begin{array}{l}\text { significantly lower NSSS and rescue } \\
\text { antihistamines; improved RRQoL in the } \\
\text { omalizumab group } \\
\text { patient evaluation of efficacy significantly } \\
\text { favored omalizumab }\end{array}$ & no difference in AE between study groups \\
\hline $\begin{array}{l}\text { Vignola } \\
\text { et al. [21] } \\
(2004)\end{array}$ & $\begin{array}{l}405 \text { subjects with concomitant } \\
\text { asthma and persistent AR } \\
\text { comparison omalizumab-placebo }\end{array}$ & $\begin{array}{l}\text { significant improvement in RRQoL in the } \\
\text { omalizumab-treated patients }\end{array}$ & $\begin{array}{l}\text { overall incidence of AE higher in the } \\
\text { omalizumab group } \\
\text { most AE were mild-moderate } \\
\text { no severe or serious AE related to } \\
\text { omalizumab }\end{array}$ \\
\hline
\end{tabular}

$\mathrm{AE}=$ Adverse events; $\mathrm{AR}=$ allergic rhinitis; NSSS = nasal symptom severity scores; $\mathrm{RRQ}$ L = rhinitis-related quality of life.

temic approach to both, upper and lower airway disease. Results from a Cochrane review [22] including mild-severe allergic asthmatic patients with high levels of IgE consequently showed a significant reduction in free $\operatorname{IgE}$ after treatment with intravenous or subcutaneous omalizumab compared to treatment with placebo. Clinically, omalizumab consistently reduced asthma exacerbations and steroid requirement in allergic asthmatics $[22,32,34,38]$. Thus, patients with persistent allergic rhinitis concomitant with asthma might represent a target group, in which omalizumab is well tolerated and effective in preventing asthma exacerbations and improving quality of life. With this concept, Vignola et al. [21] studied a group of 405 patients with moderate-severe asthma concomitant with persistent allergic rhinitis in a multicenter, randomized, double-blind, parallel-group, placebo-controlled trial. Sig- nificantly fewer patients treated with omalizumab experienced asthma exacerbations compared with placebo-treated patients. A clinically relevant and statistically significant improvement in both asthma and rhinitis quality of life questionnaires occurred in a higher percentage of the omalizumab patients than the placebo patients.

Discontinuation of omalizumab treatment is associated with increases in circulating free $\operatorname{IgE}$ within 8 weeks compared to baseline levels $[16,22]$. A recent study by Corren et al. [39] showed that an initial effect of highdose treatment with omalizumab was not fully maintained during dose reduction, and returned to baseline after discontinuation of treatment. Since it does not completely inhibit the sensitization phase or induce allergenspecific immune tolerance, anti-IgE is not a curative approach [32]. This implies that treatment should be per- 
manent or repeated every season, dependent on the symptoms, and the costs have to be weighted against the benefits and the possibility of other treatments. Investigations into the cost-effectiveness of omalizumab are lacking, but necessary. Studies comparing the effect of treatment with anti-IgE and other available treatment options for IgE-mediated airway disease are indicated [22]. Furthermore, during an allergen-mediated immune cascade, many mediators are released, which unfortunately are not targeted by anti-IgE and thus can still lead to the onset of allergic airway disease [32], as shown by results from a mouse model in which an anaphylactic reaction can occur independently from IgE [40].

Omalizumab is well tolerated. There is no presumed risk of inducing acute anaphylaxis by cross-linking IgE molecules, because omalizumab does not bind to IgE on mast cells and basophils. Adverse events following treatment with omalizumab were generally mild-moderate, and no significant differences compared to placebo were found $[16,21,22,32,34]$. The most frequent drug-related side effects were urticaria, pruritus, headache, paresthesia and administration site reactions. No serious adverse events were suspected to be related to omalizumab. However, the safety profile of omalizumab still requires longer-term assessment [22].

In any case, caution is indicated because serious and life-threatening allergic reactions (anaphylaxis) have been reported after the administration of omalizumab, as well as a serum sickness-like reactions after the seventh dose [41]. Possible symptoms and signs of such an allergic reaction have included bronchospasm, hypotension, syncope, urticaria and/or angioedema of the throat or tongue, and some of these reactions were life-threatening. In premarketing clinical trials, the frequency of anaphylaxis attributed to omalizumab was estimated to be $0.1 \%$, but increased to at least $0.2 \%$ in postmarketing spontaneous reports. Anaphylaxis can occur after the first dose, but has also occurred $>1$ year after the beginning of treatment. These reactions mostly occur within $2 \mathrm{~h}$ of administration, but can occur up to $24 \mathrm{~h}$ or even longer after subcutaneous injection of omalizumab. This is why omalizumab should only be administered after informing and educating patients about possible anaphylactic reactions and in a healthcare setting trained to manage anaphylaxis. In addition, patients should be closely observed for an appropriate period of time after administration of omalizumab (at least $2 \mathrm{~h}$ after administration of omalizumab).

Recently, there has been some interest in neoplasia adverse events because more neoplasms were reported in omalizumab-treated patients compared to control pa- tients across all completed studies. However, a causal relationship between omalizumab and cancer seemed unlikely [34]. No case of overdose has been reported. Until now, no safety data after long-term treatment with omalizumab are available.

According to Casale et al. [14], the patients who most likely benefit from treatment with omalizumab are patients with moderate-severe allergic rhinitis with proven allergen-specific antibodies who have no sufficient response to or do not accept anti-allergic medication, patients with compliance problems and patients unable to tolerate allergen IT. Finally, treatment with omalizumab would be beneficial in patients with comorbid allergic rhinitis and asthma, and is suitable for polysensitized allergic patients since it is independent of allergen specificity. However, at present, omalizumab is not only indicated in allergic rhinitis, but may also be used in patients with severe asthma and comorbid rhinitis.

According to the patient information, Xolair ${ }^{\circledR}$ is indicated as add-on therapy for patients aged $>12$ years with severe persistent allergic asthma, with a positive skin prick test or in vitro reactivity to permanently present aeroallergens and a diminished lung function $\left(\mathrm{FEV}_{1}<80 \%\right)$. These patients should regularly present symptoms during the day or awaken at night, and have suffered several documented serious asthma exacerbations in spite of daily high-dose inhalation of steroids in combination with a long-acting inhaled $\beta_{2}$-agonist. The treatment should be considered in patients with clear IgE-mediated asthma.

\section{Results from Combination with IT}

SIT modifies the natural history of allergic diseases and is considered a causal therapy in allergic disease. According to the ARIA (Allergic Rhinitis and Its Impact on Asthma) guidelines, SIT should be considered in persistent disease and when the symptoms are moderate/severe and do not respond to conventional treatment [42]. However, the beneficial application of allergen-specific subcutaneous IT is restricted especially in highly sensitized patients because of the risk of life-threatening side effects. In ovalbumin-sensitized mice, anti-IgE treatment 3 days before intradermal or intravenous injection of antigen totally prevented the development of anaphylactic reactions [43]. Thus, anti-IgE could be combined with SIT to prevent systemic side effects and possibly potentiate efficacy (table 2).

Rush IT (RIT) carries a greater risk of acute allergic reactions (including anaphylaxis) than standard subcu- 
Fig. 1. The impact of omalizumab on IgEmediated responses in allergic inflammation. APC = Antigen-presenting cell.
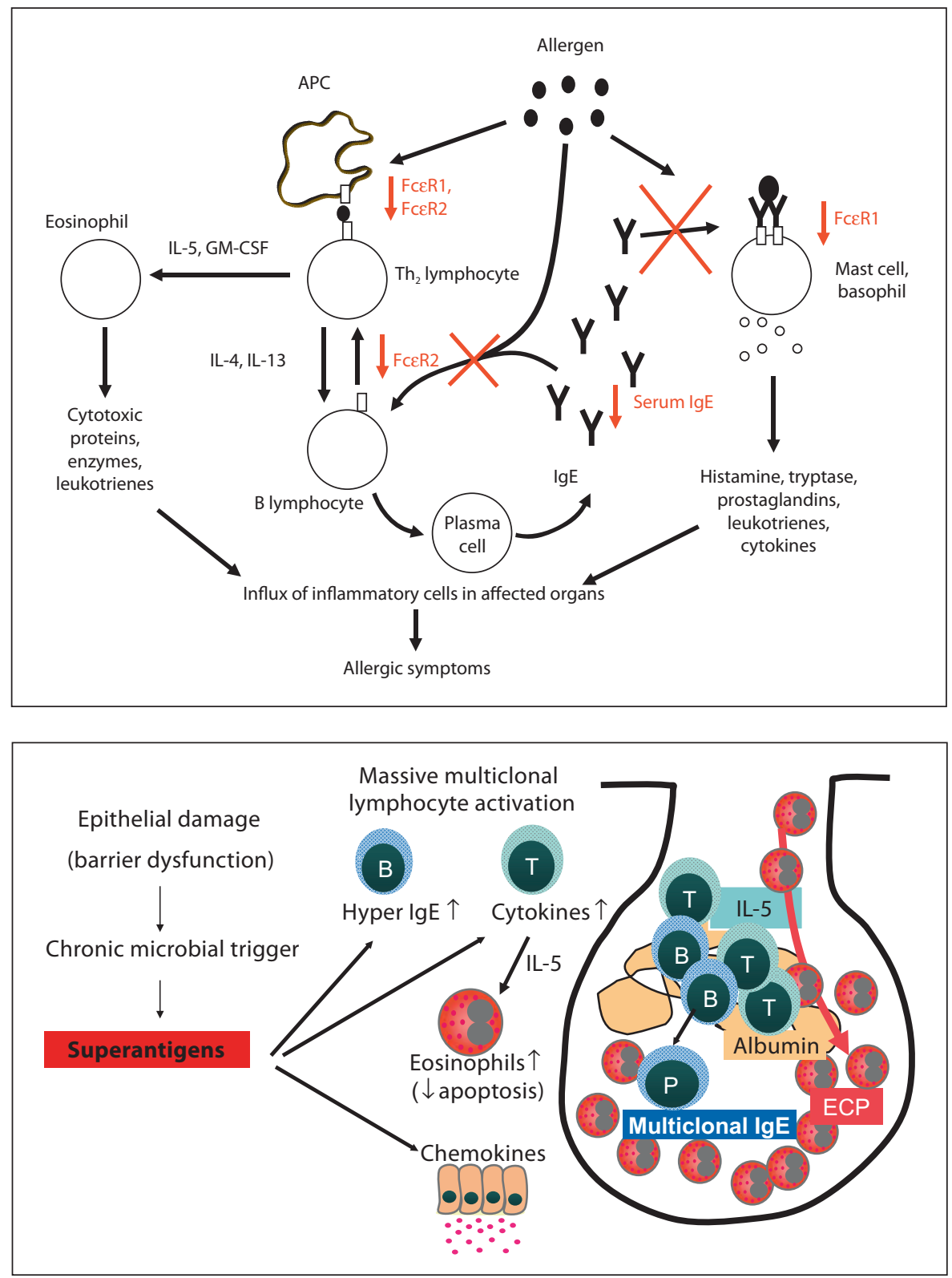

Fig. 2. Pathophysiology of $S$. aureus superantigen-driven multiclonal IgE formation in nasal polyps. Enterotoxins from $S$. aureus act as superantigens on $\mathrm{T}$ lymphocytes and induce multiclonal B-cell activation. Release of cytokines (IL-5) from $\mathrm{Th}_{2}$ cells will result in an eosinophilic activation with release of eosinophilic cationic protein (ECP). ECP causes tissue damage, edema formation and albumin accumulation. B-cell activation will result in the production of multiclonal IgE by plasma cells. taneous IT. In RIT, the accelerated dosing schedule can cause early increases in total and specific IgE concentrations that could predispose individuals to allergic reactions. The effect of omalizumab on the safety and efficacy of RIT was studied in adult patients with ragweedallergic rhinitis. Patients were randomly assigned to one of four treatment groups and received either 9 weeks of omalizumab or placebo, followed by RIT or placebo, and then 12 weeks of omalizumab or placebo plus IT [20]. Adverse events associated with RIT were most frequent in the patient group receiving IT alone; however, between the other groups only small differences were observed. IT alone was associated with a significant increase ( $>5$-fold) in the risk of adverse events compared with placebo. This significant increase was lost when RIT was combined with omalizumab: the combination only carried an approximately 2 -fold risk of adverse events compared with placebo. In addition, the efficacy of omalizumab plus IT compared to IT alone was significantly higher. Omalizumab did not affect the SIT-induced 10 -fold increase in ragweed-specific IgG levels compared with baseline. 
Table 2. Clinical studies with omalizumab in combination with specific immunotherapy

\begin{tabular}{|c|c|c|c|}
\hline Study & Patients & Outcome: efficacy & Outcome: AE \\
\hline $\begin{array}{l}\text { Casale } \\
\text { et al. [20] } \\
(2006)\end{array}$ & $\begin{array}{l}159 \text { patients with ragweed AR } \\
\text { omalizumab + placebo/ } \\
\text { omalizumab + RIT/placebo + } \\
\text { placebo/placebo + RIT }\end{array}$ & $\begin{array}{l}\text { significant improvement in severity scores } \\
\text { during the ragweed season with omalizumab } \\
\text { + IT compared to IT alone }\end{array}$ & $\begin{array}{l}\text { AE most frequent in placebo + } \\
\text { IT group, no difference } \\
\text { between other groups } \\
\text { risk of AE significantly lower } \\
\text { for the omalizumab-IT combi- } \\
\text { nation compared to IT alone }\end{array}$ \\
\hline $\begin{array}{l}\text { Kopp } \\
\text { et al. [30] } \\
(2002)\end{array}$ & $\begin{array}{l}92 \text { children with birch and grass pollen AR } \\
\text { four treatment groups: grass IT }+ \\
\text { omalizumab or placebo, birch IT }+ \\
\text { omalizumab or placebo }\end{array}$ & $\begin{array}{l}\text { symptom load was significantly reduced in } \\
\text { both omalizumab groups compared to placebo } \\
\text { in vitro sulfidoleukotriene release was signifi- } \\
\text { cantly lower with IT + omalizumab compared } \\
\text { to IT + placebo, parallel to the reduction in } \\
\text { symptoms and the use of rescue medication }\end{array}$ & no data \\
\hline
\end{tabular}

\begin{tabular}{|c|c|c|}
\hline $\mathrm{z} \mathrm{e}$ & $\begin{array}{l}225 \text { children with birch and grass pollen } \\
\text { four treatment groups: grass IT }+ \\
\text { omalizumab or placebo, birch IT }+ \\
\text { omalizumab or placebo }\end{array}$ & $\begin{array}{l}\text { combination of IT and omalizumab: no } \\
\text { pollen-induced increase in ECP and decrease } \\
\text { in tryptase in nasal secretions; significantly } \\
\text { lower tryptase levels in the omalizumab group }\end{array}$ \\
\hline
\end{tabular}

Kuehr 221 children with birch and grass pollen AR significant reduction in symptom load and

et al. [44] four treatment groups: grass IT + rescue medication use in the omalizumab +

(2002) omalizumab or placebo, birch IT + omalizumab or placebo

no data

IT group compared to IT alone; omalizumab reduced symptom load regardless of IT and had a protective effect independent of the type of allergen and additional clinical benefit to IT

Rolinck- further analyses during grass pollen season

Werninghaus after previous study [42]

et al. [45] four treatment groups: birch IT + placebo

(2004) (no effective treatment for grass pollen), birch IT + omalizumab (anti-IgE monotherapy), grass IT + placebo (IT mono-

significantly diminished rescue medication use and reduction in the number of symptomatic days with omalizumab monotherapy; superior efficacy of the omalizumab-IT combination on symptom severity compared to IT or omalizumab alone

no serious AE related to omalizumab; study drug-related $\mathrm{AE}$ were more frequent in the IT + omalizumab group compared to the IT + placebo group, but were mostly related to IT

therapy) or grass IT + omalizumab

$\mathrm{AE}=$ Adverse events; $\mathrm{AR}=$ allergic rhinitis $\mathrm{ECP}=$ eosinophilic cationic protein .

Kopp et al. [30] conducted a study in 92 children with allergic rhinitis due to sensitization to birch and grass pollen. Randomized in four groups, two groups were treated with SIT to birch pollen, and two groups to grass pollen. After 12 weeks of IT, subcutaneous placebo or anti-IgE was added for 24 weeks. In the two groups receiving grass-specific SIT, there was a statistically significant difference in the scores for daily medication use, eye symptoms and mean symptom load, and in the group treated with birch-specific SIT and anti-IgE, the symptoms were significantly lower compared to the group treated with birch-specific SIT and placebo. The combination of anti-IgE and grass SIT, as well as anti-IgE and birch SIT, resulted in significantly lower in vitro sulfidoleukotriene release in comparison to placebo combined with IT. This observation was made not only after stimu- lation with the corresponding allergen, but also after stimulation with unrelated allergen. In response to birch pollen, a significant association was shown between the use of rescue medication, the symptom load and in vitro leukotriene release after therapy. An extension of this study [5] revealed that the combination of SIT and anti$\operatorname{IgE}$ is associated with the prevention of an increase in eosinophilic cationic protein in nasal secretions during the pollen season and a decrease in tryptase levels in nasal secretions. Tryptase was significantly lower in the omalizumab-treated group compared with the placebotreated group during and after the birch pollen season.

In parallel to those studies, Kuehr et al. [44] investigated the complementary action of SIT and anti-IgE in a randomized, double-blind trial in four treatment groups. Two hundred and twenty-one patients aged between 6 
and 17 years were started on birch- or grass-specific SIT. Anti-IgE or placebo was added before and maintained during the anticipated pollen seasons for a total of 24 weeks. Combination therapy significantly reduced symptom load over the two pollen seasons compared to SIT alone. The numbers of days with rescue medication use and allergic symptoms were significantly lower in the SIT plus anti-IgE groups than in the placebo groups. Anti-IgE reliably reduced allergen-induced symptom load regardless of the nature of the allergen and the efficacy of conventional SIT when analyzed by season. A protective effect of anti-IgE treatment was demonstrated, independent of the type of allergen, and an additional clinical benefit of SIT in both pollen seasons could be seen by the significant decrease in symptom load during the pollen season for those patients receiving the relevant SIT. Further analyses to assess the effects of the two treatment options on symptom severity scores and rescue medication use were performed [45] and showed a significantly diminished rescue medication use and a reduction in the number of symptomatic days with anti-IgE monotherapy. The combination of omalizumab and SIT showed a superior effect on symptom severity compared to antiIgE or SIT alone.

Recently, a 4-arm, double-blind, placebo-controlled study was done to test ragweed allergen IT with and without omalizumab. Complete inhibition of allergen-specific IgE binding was observed in both omalizumab groups $(\mathrm{p}<0.001)$, where IT alone resulted in partial inhibition of allergen-IgE binding after 5-19 weeks of treatment compared with baseline $(p<0.01)$. Serum ragweed-specific IgG4 was measured and only increased after IT ( $p<$ $0.05)$, both in the presence and absence of anti-IgE treatment. The combination of ragweed IT and anti-IgE resulted in the induction of long-lasting inhibitory antibody function for up to 42 weeks compared with either treatment alone [46].

Considering the results of these studies, we can conclude that the combination of IT with omalizumab may provide important clinical benefits for highly selected patients. The efficacy of a combination of omalizumab and IT is higher than that of IT alone in treating symptoms of allergic rhinitis. Omalizumab is not allergen specific as opposed to IT, which makes anti-IgE especially suitable for treating polysensitized patients. During the first pollen season, patients may have incomplete control of their symptoms, in which case anti-IgE can be useful. Finally, treatment with omalizumab can be considered in some patients receiving SIT to reduce the risk of adverse events. It should be kept in mind that even though the use of the
omalizumab-IT combination has been shown to reduce the number of anaphylactic reactions, anaphylaxis may still occur. Lanier [47] reported 2 cases of anaphylaxis to SIT while being treated with omalizumab. Furthermore, as discussed previously, anaphylaxis can be caused by omalizumab monotherapy. Therefore, it cannot be recommended as a preventive measure for anaphylaxis.

\section{Rationale for Anti-lgE in Nasal Polyps and Perspectives}

About $4 \%$ of the general population, mostly adults $>45$ years, are affected by nasal polyposis, and patients suffer from nasal congestion, loss of smell, headache and significant impairments in daily activities. Nasal polyps are often bilateral and associated with non-allergic asthma and aspirin sensitivity. It has repeatedly been shown that nasal polyp patients are not more frequently atopic (skin test positive) than healthy controls, and allergen exposure does not induce symptoms or mediator release in nasal polyposis [7]. However, significantly elevated concentrations of IgE antibodies have been discovered in polyps, which were recently related to Staphylococcus aureus enterotoxins rather than atopy. Nasal polyposis is treated with local or systemic glucocorticosteroids, and often endoscopic sinus surgery is necessary; recurrence rates are high, with conservative or medical treatment, and often induce adverse events.

Nasal polyps present as edematous masses in the nasal and paranasal cavities, originating from the middle meatus and ethmoid cells. An edematous-fibrotic tissue with a reduced number of vessels and glands, and virtually no neural structures, with frequent epithelial damage and a thickened basement membrane is seen on histomorphologic examination [48]. The etiology and pathogenesis of nasal polyposis are still not fully understood. A prominent local eosinophilic tissue inflammation characterizes these nasal polyps [1,48-51]. This has been shown to be related to IL-5 [52], which prolongs survival of eosinophils. Furthermore, increased migration of eosinophils via RANTES and eotaxin into the tissue, in combination with reduced apoptosis, may account for the increased cell numbers [48]. Also, elevated levels of eosinophilic cationic protein and an upregulation of cysteinyl-leukotriene synthesis have been described in nasal polyp tissue [1, 48, 51]. Elevated levels of local total and specific IgE are measured in nasal polyps, and in most studies the number of degranulating epithelial mast cells in nasal polyps is high $[49,50,53]$. 
A recent study by Bachert et al. [1] suggested that these elevated IgE concentrations are related to the eosinophilic inflammation in nasal polyp tissue, indicating a role for $\mathrm{IgE}$ in the pathogenesis of nasal polyposis. In this study, three nasal polyp groups could be defined based on the presence of specific IgE antibodies. No measurable specific IgE and low total IgE concentrations were found in group 1, being in contrast to group 2 presenting with measurable specific IgE levels and increased total IgE levels. Finally, group 3 demonstrated multiclonal specific IgE (including IgE to $S$. aureus enterotoxins) and a high prevalence of asthma, pointing to a possible pathophysiological role of bacterial superantigens $[1,49,50]$. Evidence accumulates that $S$. aureus colonizes nasal polyps, and enterotoxins released by S. aureus act as superantigens and induce a topical multiclonal IgE formation combined with a severe eosinophilic inflammation [50]. Figure 2 depicts the S. aureusinduced changes resulting in multiclonal IgE formation and eosinophilic inflammation in nasal polyps.

With respect to $S$. aureus superantigens, nasal polyps may have pathophysiologic mechanisms in common with asthma $[1,3]$. IgE antibodies to $S$. aureus enterotoxins were found in a significantly higher concentration in serum from patients with severe asthma compared to controls, suggesting a relationship between the presence of IgE antibodies to $S$. aureus enterotoxins and the severity of asthma [2]. Patients with nasal polyps and comorbid asthma or aspirin sensitivity had even higher rates of colonization, higher IgE responses to S. aureus enterotoxins as well as eosinophilic cationic protein and total IgE in nasal polyp tissue. Formation of IgE to $S$. aureus enterotoxins in nasal polyp tissue was strongly associated with asthma in patients with nasal polyps. As the immune response to superantigens leads to a modulation of the severity of eosinophilic inflammation, this may link lower airway morbidity to nasal polyposis [54].

In experiments exposing basophils armed with specific IgE to enterotoxin B, degranulation of the cells could be demonstrated [55]. Thus, enterotoxin-specific IgE antibodies could contribute to the disease via the degranulation of mast cells in polyp tissue as well as other $\operatorname{IgE}$ antibodies with specificities against inhalant allergens. Indeed, because of the multiclonality, hundreds of allergens could possibly induce a constant degranulation of those mast cells, which is actually observed in polyp tissue. Based on these observations, anti-IgE treatment could be expected to suppress the IgE-mediated inflammatory cascade in severe or recurrent nasal polyposis and non-atopic severe asthma, similarly to its activity in allergic respiratory disorders.

A retrospective analysis of two patient groups with atopic asthma and nasal polyps treated with endoscopic surgery was done by Penn and Mikula [56]. The treatment group $(n=4)$ receiving omalizumab postoperatively was compared to a control group $(n=4)$. Both groups were evaluated by sinus CT and nasal endoscopic examination, and no significant improvement was seen in CT scores, but nasal polyp scores improved significantly in the group treated with omalizumab. The investigators also reported a correlation between nasal polyp severity and total serum IgE levels in the subjects collectively.

However, there are some points of concern in the selection of patients and expectations of treatment success. Observations of increased IgE concentrations in nasal polyp tissue were unrelated to skin prick test positivity, in contrast to allergic rhinitis. Local IgE in the polyp tissue is also often unrelated to serum IgE, rendering the selection of patients more difficult. Local IgE levels might be very high, exceeding $1,000 \mathrm{kU} / \mathrm{l}$, and difficult to decrease by anti-IgE treatment due to distribution properties, whereas serum IgE may be low and lead to an insufficient dose of omalizumab to be administered according to current recommendations. In the case of a positive response to treatment, however, the proof of concept would be established and would pave the way for omalizumab treatment for nasal polyposis and probably also chronic severe non-atopic asthma. This proof-of-concept study is currently carried out at the Upper Airways Research Laboratory of the Department of Otorhinolaryngology of the Ghent University Hospital.

\section{Discussion and Future Prospects}

Treatment of allergic rhinitis with omalizumab has been shown to be beneficial regarding symptom reduction. The combination of omalizumab and SIT may offer increased safety in appropriate patients, in addition to an increase in efficacy. In nasal polyp disease, evidence accumulates that $S$. aureus-derived enterotoxins act as superantigens resulting in $\mathrm{T}$ - and $\mathrm{B}$-cell activation with massive IgE formation. A proof-of-concept trial with omalizumab as treatment in patients with nasal polyps is currently conducted. In case of a positive therapeutic response, this would open the door for anti-IgE treatment approaches for severe non-atopic lower airway disease.

Currently, however, there are some factors due to which it is unlikely that omalizumab will shortly be approved for 
the treatment of allergic rhinitis patients and patients with nasal polyposis. Although allergic rhinitis and nasal polyposis are severely debilitating diseases with important impacts on quality of life, they are not life-threatening, and omalizumab is a symptomatic treatment and would require multiple dosages. The high costs of treatment with omalizumab, the high frequency of allergic rhinitis and nasal polyps, as well as the current lack of data concerning safety in long-term application of omalizumab should be borne in mind. To address these questions, further studies have to be conducted. However, omalizumab was found to be cost-effective in the treatment of patients with inadequately controlled severe persistent allergic asthma compared with treatment with high-dose inhaled corticosteroids plus a long-acting $\beta_{2}$-agonist [57].
Possible future perspectives in allergic disease include inhibition of human mast cell proliferation by tamoxifen [58]. A study by Duffy et al. [58] suggests that tamoxifen might be useful in the treatment of mast cell-mediated diseases. Other perspectives are small-molecule chemokine receptor antagonists causing inhibition of chemokine receptors on eosinophils and basophils [59]. With respect to nasal polyps, preliminary data on omalizumab treatment suggest promising results in non-atopic disease, too. Further studies are underway.

\section{Acknowledgments}

This work was partially supported by grants to Claus Bachert from the Flemish Scientific Research Board (FWO, A12/5-HBKH3 and F6/15-DP.D7675).

\section{References}

1 Bachert C, Gevaert P, Holtappels G, Johansson SGO, Van Cauwenberge P: Total and specific IgE in nasal polyps is related to local eosinophilic inflammation. J Allergy Clin Immunol 2001;107:607-614.

-2 Bachert C, Gevaert P, Howarth P, Holtappels $\mathrm{G}$, van Cauwenberge P, Johansson SGO: IgE to Staphylococcus aureus enterotoxins in serum is related to severity of asthma. J Allergy Clin Immunol 2003;111:1131-1132.

-3 Van Zele T, Gevaert P, Watelet JB, Claeys G, Holtappels G, Claeys C, van Cauwenberge P, Bachert C: Staphylococcus aureus colonization and $\operatorname{IgE}$ antibody formation to enterotoxins is increased in nasal polyposis. J Allergy Clin Immunol 2004;114:981-983.

$\checkmark 4$ Hanf G, Noga O, O’Connor A, Kunkel G: Omalizumab inhibits allergen challenge-induced nasal response. Eur Respir J 2004;23: 414-418.

5 Bez C, Schubert R, Kopp M, Ersfeld Y, Rosewich M, Kuehr J, Kamin W, Berg AV, Wahn U, Zielen S: Effect of anti-immunoglobulin E on nasal inflammation in patients with seasonal allergic rhinoconjunctivitis. Clin Exp Allergy 2004;34:1079-1085.

-6 Verhaeghe B, Gevaert P, Holtappels G, Lukat KF, Lange B, Van Cauwenberge P, Bachert C: Up-regulation of IL-18 in allergic rhinitis. Allergy 2002;57:825-830.

7 Keith PK, Conway M, Evans S, Wong DA, Jordana G, Pengelly D, Dolovich J: Nasal polyps: effects of seasonal allergen exposure. J Allergy Clin Immunol 1994;93:567-574.

$\checkmark 8$ Lichtenstein LM, Ishizaka K, Norman PS, Sobotka AK, Hill BM: IgE antibody measurements in ragweed hay fever. J Clin Invest 1973;52:472-482.
9 MacGlashan DW Jr, Bochner BS, Adelman DC, Jardieu PM, Togias A, McKenzie-White J, Sterbinsky SA, Hamilton RG, Lichtenstein LM: Down-regulation of FceRI expression on human basophils during in vivo treatment of atopic patients with anti-IgE antibody. J Immunol 1997;158:1438-1445.

10 Holgate S, Casale T, Wenzel S, Bousquet J, Deniz Y, Reisner C: The anti-inflammatory effects of omalizumab confirm the central role of IgE in allergic inflammation. J Allergy Clin Immunol 2005;115:459-465.

11 Williams CMM, Galli SJ: The diverse potential effector and immunoregulatory roles of mast cells in allergic disease. J Allergy Clin Immunol 2000;105:847-859.

12 Pirron U, Schlunck T, Prinz JC, Rieber EP: IgE-dependent antigen focusing by human $\mathrm{B}$ lymphocytes is mediated by the low-affinity receptor for IgE. Eur J Immunol 1990;20: 1547-1551

13 Corne J, Djukanovic R, Thomas L, Warner J, Botta L, Grandordy B, Gygax D, Heusser C, Patalano F, Richardson W, Kilcherr E, Staehelin T, Davis F, Gordon W, Sun L, Liou R, Wang G, Chang T-W, Holgate S: The effect of intravenous administration of a chimeric anti-IgE antibody on serum IgE levels in atopic subjects: efficacy, safety, and pharmacokinetics. J Clin Invest 1997;99:879-887.

14 Casale TB, Condemi J, LaForce C, Nayak A, Rowe M, Watrous M, McAlary M, FowlerTaylor A, Racine A, Gupta N, Fick R, Della Cioppa G: Effect of omalizumab on symptoms of seasonal allergic rhinitis. A randomized controlled trial. JAMA 2001;286:29562967.
15 Ädelroth E, Rak S, Haahtela T, Aasand G, Rosenhall L, Zetterstrom O, Byrne A, Champain K, Thirlwell J, Della Cioppa G, Sandström T: Recombinant humanized $\mathrm{mAb}-\mathrm{E} 25$, an anti-IgE mAb, in birch polleninduced seasonal allergic rhinitis. J Allergy Clin Immunol 2000;106:253-259.

16 Casale TB, Bernstein IL, Busse WW, LaForce CF, Tinkelman DG, Stoltz RR, Dockhorn RJ, Reimann J, Su JQ, Fick RB, Adelman DC: Use of anti-IgE humanized monoclonal antibody in ragweed-induced allergic rhinitis. J Allergy Clin Immunol 1997;100:110-121.

17 Settipane RA, Charnock DR: Epidemiology of rhinitis: allergic and nonallergic. Clin Allergy Immunol 2007;19:23-34.

18 Van Cauwenberge P: Nasal sensitization (review). Allergy 1997;52(33 suppl):7-9.

19 Poole JA, Meng J, Reff M, Spellman MC, Rosenwasser LJ: Anti-CD23 monoclonal antibody, lumiliximab, inhibited allergen-induced responses in antigen-presenting cells and $\mathrm{T}$ cells from atopic subjects. J Allergy Clin Immunol 2005; 116:780-788.

20 Casale TB, Busse WW, Kline JN, Ballas ZK, Moss MH, Townley RG, Mokhtarani M, Seyfert-Margolis V, Asare A, Bateman K, Deniz Y, Immune Tolerance Network Group: Omalizumab pretreatment decreases acute reactions after rush immunotherapy for ragweed-induced seasonal allergic rhinitis. J Allergy Clin Immunol 2006;117:134-140.

21 Vignola AM, Humbert M, Bousquet J, Boulet L-P, Hedgecock S, Blogg M, Fox H, Surrey K: Efficacy and tolerability of anti-immunoglobulin E therapy with omalizumab in patients with concomitant allergic asthma and persistent allergic rhinitis: SOLAR. Allergy 2004;59:709-717. 
22 Walker S, Monteil M, Phelan K, Lasserson TJ, Walters EH: Anti-IgE for chronic asthma. Cochrane Database Syst Rev 2002, CD003559.

23 Babu KS, Arshad SH, Holgate ST: Anti-IgE treatment: an update. Allergy 2001;56:11211128.

-24 Lin H, Boesel KM, Griffith DT, Prussin C, Foster B, Romero FA, Townley R, Casale TB: Omalizumab rapidly decreases nasal allergic response and FceRI on basophils. J Allergy Clin Immunol 2004;113:297-302.

25 Plewako H, Arvidsson M, Petruson K, Oancea I, Holmberg K, Ädelroth E, Gustafsson H, Sandström T, RakS: The effect of omalizumab on nasal allergic inflammation. J Allergy Clin Immunol 2002;110:68-71.

-26 Prussin C, Griffith DT, Boesel KM, Lin H, Foster B, Casale TB: Omalizumab treatment downregulates dendritic cell FceRI expression. J Allergy Clin Immunol 2003;112:11471154.

27 Chang TW: The pharmacological basis of anti-IgE therapy. Nat Biotechnol 2000;18: 157-162.

28 Beck LA, Marcotte GV, MacGlashan D, Togias A, Saini S: Omalizumab-induced reductions in mast cell Fc epsilon RI expression and function. J Allergy Clin Immunol 2004; 114:527-530.

-29 Ong YE, Menzies-Gow A, Barkans J, Benyahia F, Ou T-T, Ying S, Kay AB: Anti-IgE (omalizumab) inhibits late-phase reactions and inflammatory cells after repeat skin allergen challenge. J Allergy Clin Immunol 2005;116:558-564.

-30 Kopp MV, Brauburger J, Riedinger F, Beischer D, Ihorst G, Kamin W, Zielen S, Bez C, Friedrichs F, Von Berg A, Gerhold K, Hamelmann E, Hultsch T, Kuehr J: The effect of anti-IgE treatment on in vitro leukotriene release in children with seasonal allergic rhinitis. J Allergy Clin Immunol 2002;110:728735.

- 31 Fox JA, Hotaling TE, Struble C, Ruppel J, Bates DJ, Schoenhoff MB: Tissue distribution and complex formation with $\operatorname{IgE}$ of an anti-IgE antibody after intravenous administration in cynomolgus monkeys. J Pharmacol Exp Ther 1996;279:1000-1008.

- 32 Hamelmann E, Rolinck-Werninghaus C, Wahn U: Is there a role for anti-IgE in combination with specific allergen immunotherapy? Curr Opin Allergy Clin Immunol 2003; 3:501-510.

- 33 Fahy JV, Cockcroft DW, Boulet L-P, Wong HH, Deschesnes F, Davis EE, Ruppel J, Su JQ, Adelman DC: Effect of aerosolized anti-IgE (E25) on airway responses to inhaled allergen in asthmatic subjects. Am J Respir Crit Care Med 1999; 160:1023-1027.

- 34 Holgate ST, Djukanovic R, Casale T, Bousquet J: Anti-immunoglobulin $\mathrm{E}$ treatment with omalizumab in allergic diseases: an update on anti-inflammatory activity and clinical efficacy. Clin Exp Allergy 2005;35:408416.
35 Casale TB: Anti-immunoglobulin E (omalizumab) therapy in seasonal allergic rhinitis. Am J Respir Crit Care Med 2001;164:S18S21.

36 Nayak A, Casale TB, Miller SD, Condemi J, McAlary M, Fowler-Taylor A, Della Cioppa G, Gupta N: Tolerability of retreatment with omalizumab, a recombinant humanized monoclonal anti-IgE antibody, during a second ragweed pollen season in patients with seasonal allergic rhinitis. Allergy Asthma Proc 2003;24:323-329.

37 Chervinsky P, Casale TB, Townley R, Tripathy I, Hedgecock S, Fowler-Taylor A, Shen H, Fox H: Omalizumab, an anti-IgE antibody, in the treatment of adults and adolescents with perennial allergic rhinitis. Ann Allergy Asthma Immunol 2003;91:160-167.

38 Milgrom H: Anti-IgE therapy in allergic disease. Curr Opin Pediatr 2004;16:642-647.

- 39 Corren J, Shapiro G, Reimann J, Deniz Y, Wong D, Adelman D, Togias A: Allergen skin tests and free IgE levels during reduction and cessation of omalizumab therapy. J Allergy Clin Immunol 2008;121:506-511.

40 Oettgen HC, Martin TR, Wynshaw-Boris A, Deng C, Drazen JM, Leder P: Active anaphylaxis in IgE-deficient mice. Nature 1994;370 367-370.

41 Dreyfus DH, Randolph CC: Characterization of an anaphylactoid reaction to omalizumab. Ann Allergy Asthma Immunol 2006; 96:624-627.

42 Van Cauwenberge P: ARIA: impact of compliance. Clin Exp Allergy Rev 2005;5:3-6.

43 Hamelmann E, Cieslewicz G, Schwarze J, Ishizuka T, Joetham A, Heusser C, Gelfand EW: Anti-interleukin 5 but not anti-IgE prevents airway inflammation and airway hyperresponsiveness. Am J Respir Crit Care Med 1999;160:934-941.

44 Kuehr J, Brauburger J, Zielen S, Schauer U, Kamin W, Von Berg A, Leupold W, Bergmann K-C, Rolinck-Werninghaus C, Gräve M, Hultsch T, Wahn U, Omalizumab Rhinitis Study Group: Efficacy of combination treatment with anti-IgE plus specific immunotherapy in polysensitized children and adolescents with seasonal allergic rhinitis. J Allergy Clin Immunol 2002;109:274-280.

45 Rolinck-Werninghaus C, Hamelmann E, Keil T, Kulig M, Koetz K, Gerstner B, Kuehr J, Zielen S, Schauer U, Kamin W, von Berg A, Hammermann J, Weinkauf B, Weidinger G, Stenglein S, Wahn U, Omalizumab Rhinitis Study Group: The co-seasonal application of anti-IgE after preseasonal specific immunotherapy decreases ocular and nasal symptom scores and rescue medication use in grass pollen allergic children. Allergy 2004;59: 973-979.

46 Klunker S, Saggar LR, Seyfert-Margolis V Asare AL, Casale TB, Durham SR, Francis JN, Immune Tolerance Network Group: Combination treatment with omalizumab and rush immunotherapy for ragweed-induced allergic rhinitis: inhibition of IgE-fa- cilitated allergen binding. J Allergy Clin Immunol 2007;120:688-695.

47 Lanier BQ: Unanswered questions and warnings involving anti-immunoglobulin $\mathrm{E}$ therapy based on 2-year observation of clinical experience. Allergy Asthma Proc 2005;26: 435-439.

48 Bachert C, Wagenmann M, Rudack C, Höpken K, Hillebrandt M, Wang D, Van Cauwenberge $\mathrm{P}$ : The role of cytokines in infectious sinusitis and nasal polyposis. Allergy 1998;53:2-13

- 49 Bachert C, Gevaert P, Holtappels G, van Cauwenberge P: Mediators in nasal polyposis. Curr Allergy Asthma Rep 2002;2:481-487.

50 Perez-Novo CA, Kowalski ML, Kuna P, Ptasinska A, Holtappels G, Van Cauwenberge P, Gevaert P, Johannson S, Bachert C: Aspirin sensitivity and IgE antibodies to Staphylococcus aureus enterotoxins in nasal polyposis: studies on the relationship. Int Arch Allergy Immunol 2004;133:255-260.

51 Bachert C, Gevaert P, Holtappels G, Cuvelier C, Van Cauwenberge P: Nasal polyposis: from cytokines to growth. Am J Rhinol 2000;14:279-290.

52 Simon Hans-Uwe, Yousefi S, Schranz C, Schapowal A, Bachert C, Blaser K: Direct demonstration of delayed eosinophil apoptosis as a mechanism causing tissue eosinophilia. J Immunol 1997;158:3902-3908.

53 Mygind N, Dahl R, Bachert C: Nasal polyposis, eosinophil dominated inflammation, and allergy. Thorax 2000;55(suppl 2):S79S83.

54 Zhang N, Gevaert P, Van Zele T, Perez-Novo C, Patou J, Holtappels G, Van Cauwenberge P, Bachert C: An update on the impact of Staphylococcus aureus enterotoxins in chronic sinusitis with nasal polyposis. Rhinology 2005;43:162-168.

55 Leung DY, Harbeck R, Bina P, Reiser RF, Yang E, Norris DA, Hanifin JM, Sampson HA: Presence of IgE antibodies to staphylococcal exotoxins on the skin of patients with atopic dermatitis. Evidence for a new group of allergens. J Clin Invest 1993;92:13741380.

56 Penn R, Mikula S: The role of anti-IgE immunoglobulin therapy in nasal polyposis: a pilot study. Am J Rhinol 2007;21:428-432.

57 Sullivan SD, Turk F: An evaluation of the cost-effectiveness of omalizumab for the treatment of severe allergic asthma. Allergy 2008;63:670-684.

58 Duffy SM, Lawley WJ, Kaur D, Yang W, Bradding P: Inhibition of human mast cell proliferation and survival by tamoxifen in association with ion channel modulation. J Allergy Clin Immunol 2003;112:965-972.

- 59 Bryan SA, Jose PJ, Topping JR, Wilhelm R, Soderberg C, Kertesz D, Barnes PJ, Williams TJ, Hansel TT, Sabroe I: Responses of leukocytes to chemokines in whole blood and their antagonism by novel CC-chemokine receptor 3 antagonists. Am J Respir Crit Care Med 2002;165:1602-1609. 